\section{NO. 100}

OCTOBER

2018

\section{KEYPOINTS}

- Escalating trade tensions between the United States and the People's Republic of China prompt the Association of Southeast Asian Nations (ASEAN) to build greater complementarity among the member economies and enhance their economic and financial resilience through (i) diversifying their economic and trade structure, (ii) upgrading competitiveness and innovative capacity via domestic and regulatory reforms, and (iii) supporting high quality regional trade agreements to promote regional economic integration.

- Over time, ASEAN economies have become more services-oriented; the share of regional demand on their exports of goods and servicesincluding tourism - has been rising; also, the product composition and market destination of their exports are more diversified-all of which lessens the impact of escalating trade tensions.

- Liberalizing services will (i) attract more foreign direct investments in telecommunications, financial and business services; (ii) increase use of digital technology and e-commerce; and (iii) boost services trade (including tourism). Investing in greater services infrastructure, is also important.

- Promoting greater regional cooperation and integration to better attain a more open ASEAN Economic Community will help increase market size, exploit economies of scale, and enhance competitiveness and innovation.

- Speeding up implementation of both the Regional Comprehensive Economic Partnership and Comprehensive and Progressive Agreement for Trans-Pacific Partnership is another effective way to lock in the gains from existing free trade agreements and help promote deeper integration across the region.

ISBN 978-92-9261-346-4 (print) ISBN 978-92-9261-347-1 (electronic) ISSN 2071-7202 (print) ISSN 2218-2675 (electronic) Publication Stock No. BRF189578-2 DOI: http://dx.doi.org/10.22617/BRF189578-2

\section{Building Complementarity and Resilience in ASEAN amid Global Trade Uncertainty ${ }^{1}$}

\section{INTRODUCTION}

Growing bilateral trade tensions between the United States (US) and the People's Republic of China (PRC) are a concern for members of the Association of Southeast Asian Nations (ASEAN). Most ASEAN economies are open and benefit from export-led growth. They have significant trade ties with the US and the PRC and also export goods - such as electronics or automobiles-now targeted by US trade restrictions. In the near term, the US-PRC trade tensions will likely undermine global trade by raising import prices.

Latest figures show that both the US and the PRC remain important ASEAN trading partners. The PRC share of total ASEAN trade has increased significantly-from 4\% in 2000 to $17 \%$ in 2017. Meanwhile, the US trade share declined from $17 \%$ in 2000 to $9 \%$ in 2017. In value-added terms, both the US and the PRC still absorb a sizable share of ASEAN's exports. In 2015, the US absorbed 15\% of the region's value-added exports, while the PRC took 9\%-their combined share is equivalent to nearly a quarter of the region's total value-added exports; and much larger than that absorbed within ASEAN itself (17\%).

Manufactured goods - tightly interwoven in Asia's regional value chain (including the PRC) - are a key component of ASEAN trade. In 2016, the share of manufactured goods in both exports and imports remained at about $67 \%$ of total trade. Electronic products and electric raw materials are the most traded manufactured goods-holding a $31 \%$ share of exports and $26 \%$ share of imports. This underscores the importance of the ASEAN4, ${ }^{2}$ Singapore, and Viet Nam in the assembly line for electrical and electronic products within the regional and global supply chain. The large share of manufactured electronics and transport equipment exports is thus a key concern for ASEAN as these export products pass through the PRC before final shipment to thirdcountry markets, such as the US.

1 The brief was prepared by a team led by James Villafuerte, Fahad Khan, and Mara Claire Tayag from the Regional Cooperation and Integration Division, Economic Research and Regional Cooperation Department; and Thiam Hee Ng, Kwang Jo Jeong, and Dulce Zara from the Regional Cooperation and Operations Coordination Division, Southeast Asia Department. The authors thank Yasuyuki Sawada, Cyn-Young Park, and F. Cleo Kawawaki for their valuable comments. Guy Sacerdoti edited the brief; Erickson Mercado provided the layout. Paul Mariano, Suzette Dagli, Dorothea Ramizo, Pilar Dayag, and Cindy Jane Justo provided excellent research and data support. The Association of Southeast Asian Nations (ASEAN) includes Brunei Darussalam, Cambodia, Indonesia, the Lao People's Democratic Republic, Malaysia, Myanmar, the Philippines, Singapore, Thailand, and Viet $\mathrm{Nam}$. Asia refers to the 48 regional members of ADB (45 developing members, including ASEAN, plus Australia, Japan, and New Zealand).

2 Middle-income ASEAN economies: Indonesia, Malaysia, the Philippines, and Thailand. 
Figure 1: Output Share of Manufacturing and Services (\%)
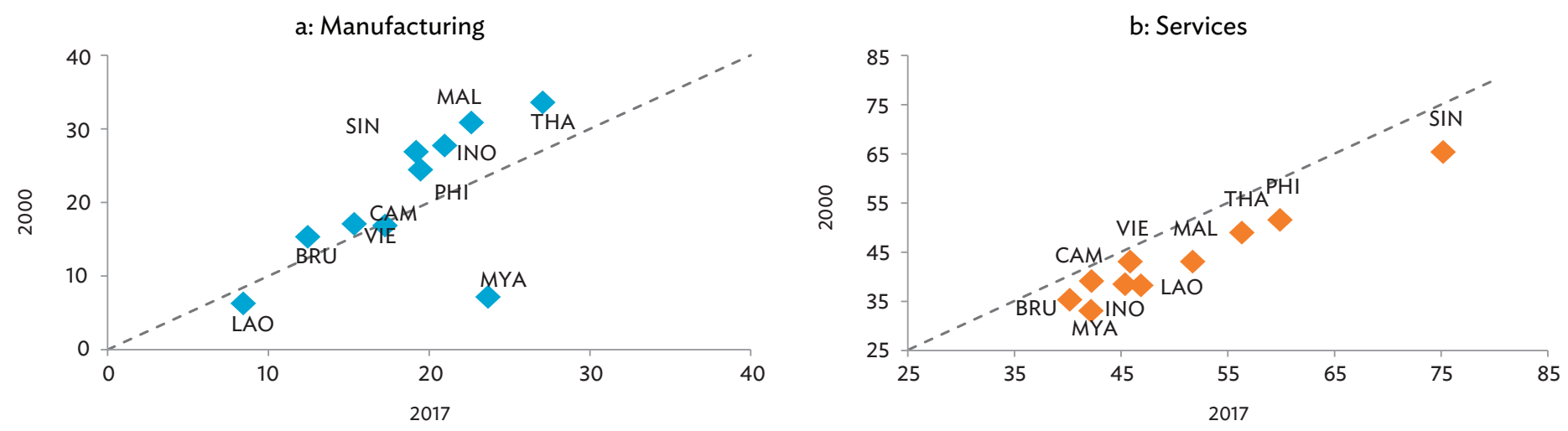

BRU = Brunei Darussalam, CAM = Cambodia, INO = Indonesia, GNI = gross national income, LAO = Lao People's Democratic Republic, MAL = Malaysia, MYA = Myanmar, $\mathrm{PHI}=$ Philippines, $\mathrm{SIN}=$ Singapore, $\mathrm{THA}=$ Thailand, $\mathrm{VIE}=$ Viet Nam.

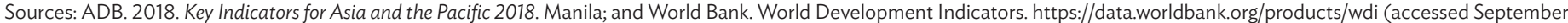
2018).

The escalation of US-PRC trade tensions will have both direct and indirect effects on ASEAN. The direct impact will likely be negative - as global trade falls due to the increase in import prices. The indirect impact-which would include possible trade diversion or creation effects-could be positive, particularly for countries that compete with the PRC in the export goods market. So far, based on existing studies, the impact of the first set of US tariffs imposed this year-equivalent to about $\$ 50$ billion-is nil. For additional threatened tariffs-equivalent to $\$ 200$ billion for the PRC and retaliatory tariffs of about $\$ 60$ billion for the US-the impact would also be modest. ${ }^{3}$

\section{ECONOMIC TRANSFORMATION AND EMERGING SERVICES IN ASEAN}

Over the years, ASEAN economies have undergone structural transformation that strengthened both their economic resilience and trade performance. This transformation now offers opportunities to help members cope with the ongoing threat of escalating trade tensions.

\section{Since the 1990s, services have gained importance in ASEAN; its share of GDP increased while manufacturing's share (in some economies) either stagnated or declined.}

Cambodia, the Lao People's Democratic Republic (Lao PDR), Myanmar, and Viet Nam were predominantly agriculture economies in the early 1990s, but for the most part have expanded their industrial and services shares since. More so, Indonesia, Malaysia, the Philippines, Singapore, and Thailand are no longer predominantly agricultural and saw their share of agriculture in output decline. While manufacturing has stagnated or declined in these countries, their services shares rose, implying that, now more than ever, ASEAN is in a much better position to withstand the effects of escalating trade tensions - which mainly affect goods trade (Figure 1).

In 2017, services accounted for more than half (53\%) of ASEAN's total output. Malaysia, the Philippines, Singapore, and Thailand had the highest services shares ranging from $52 \%$ in Malaysia to $75 \%$ in Singapore. At the industry level, wholesale and retail trade, repair of motor vehicles and motorcycles, and accommodation and food service activities collectively comprised nearly a fifth of the ASEAN's total output. Across member economies (with the exception of Brunei Darussalam), wholesale and retail trade, including repair of motor vehicles and motorcycles, was the largest service industry contributor to national GDP, with country-level shares ranging from 10\% in Cambodia to 21\% in Myanmar.

\section{REGIONAL DEMAND FOR ASEAN EXPORTS}

\section{While ASEAN economies have relied on exports to achieve rapid economic growth, strong intra-ASEAN trade and the rising inter-subregional trade with the rest of Asia could provide a buffer against external shocks.}

By value, exports from ASEAN more than tripled between 2000 and 2017-average annual growth was 7\%. Also, ASEAN's trade integration with itself and the rest of Asia has remained strong (Figure 2). ASEAN's intra-subregional trade share hovered around $23 \%$ during the last 2 years, down slightly from 24\% in 2000. Nonetheless, it remains the second highest in Asia, behind East Asia (36\% in 2017). ASEAN's trade with the rest of Asia also continues to strengthen, with its inter-subregional trade share (excluding the PRC and Japan) increasing to 21\% in 2017 from $18 \%$ in $2000 .{ }^{4}$ The high intra-ASEAN trade and the rising intersubregional trade with the rest of Asia-accounting for $44 \%$ of total trade-serve as a buffer against the effects of escalating trade tensions.

3 See ADB. 2018. Asian Development Outlook Update 2018. Manila.

4 Japan was excluded in the calculation of inter-subregional trade share as its trade with ASEAN has declined and had been substituted by complementary foreign direct investment outflows from Japan to ASEAN. This trend reflects the rising demand from ASEAN which has led many Japanese firms to put up factories outside Japan, including ASEAN, which negatively affected Japan's exports to these economies. 
Figure 2: Asia Intra- and Inter-Subregional Trade Shares (\%)

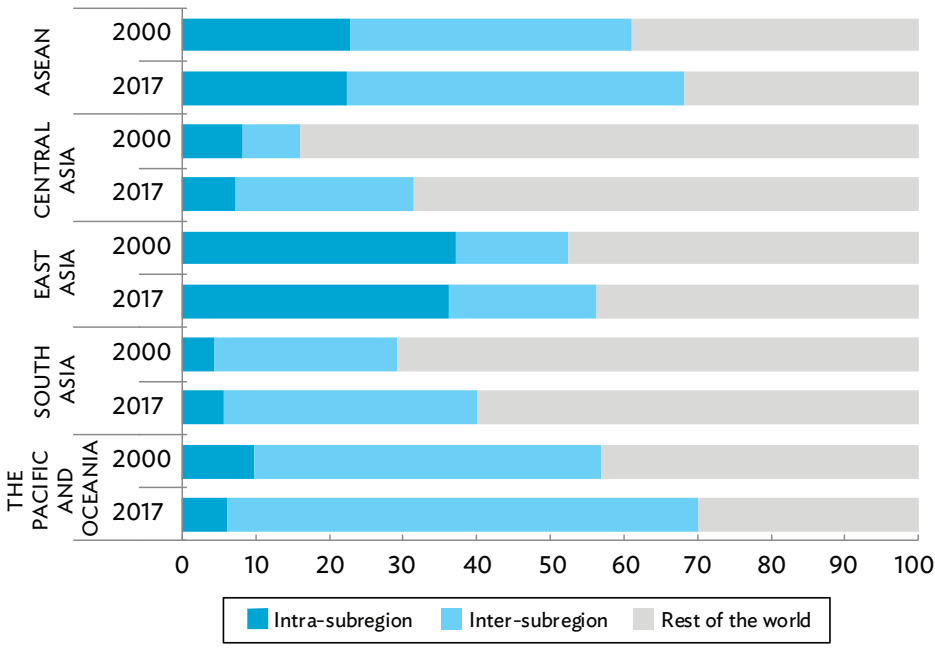

ASEAN = Association of Southeast Asian Nations.

Source: ADB. 2017. Asian Economic Integration Report 2017. Manila; updated using data from International Monetary Fund. Direction of Trade Statistics. https://www.imf.org/en/Data (accessed May 2018)

\section{By composition, intermediate goods remain a major} component of ASEAN merchandise trade; but recently the share of consumption goods has increased-partly reflecting stronger regional demand.

In 2016, intermediate goods accounted for $56 \%$ of ASEAN exports. These are mostly intermediate processed goods crisscrossing the ASEAN5 region. However, the share of intermediate goods declined steadily since peaking at 61\% in 2011. All ASEAN economies, except for the Philippines and Singapore, saw a decline of this share between 2011 and 2016. During the same period, the share of consumption goods increased across ASEAN, except in Viet Nam. In aggregate, the share of consumption goods-mostly processed goods-rose to $21 \%$ of ASEAN exports in 2016 from $16 \%$ in 2011. The increasing share of consumption goods exports primarily reflect the growing demand from a large, young, and growing population in the region.

\section{Another sector where domestic and regional demand is important is tourism.}

International tourism generated $\$ 123$ billion in revenues for ASEAN in 2016, after growing an annual average of $12 \%$ between 2003 and 2016 (Figure 3). During 2016, 110 million tourists visited ASEAN, up from 36 million in 2000. The majority of visitors to ASEAN come from within Asia (85\% of total), with $43 \%$ intraASEAN. As the region's middle class grows further, it is expected that regional demand for consumption goods and services (including tourism) will increase further, adding substantially to the region's output and trade growth.
Figure 3: International Tourism Receipts in ASEAN

(\%, annual average growth, 2003-2016)

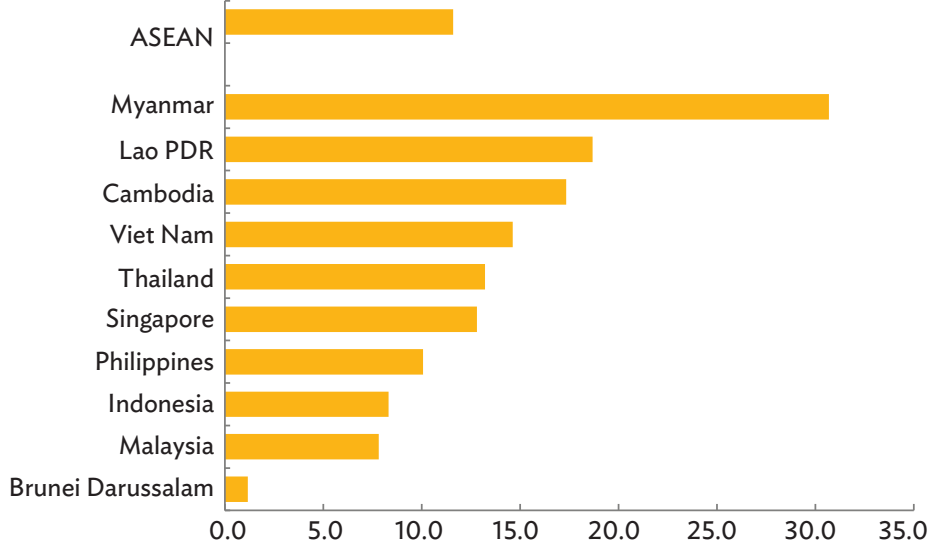

ASEAN = Association of Southeast Asian Nations, Lao PDR = Lao People's Democratic Republic.

Sources: ADB calculations using data from World Bank. World Development Indicators. http://databank.worldbank.org; and International Monetary Fund. World Economic Outlook April 2018 Database. https://www.imf.org/external/pubs/ft/weo/2018/01/ weodata/index aspx (both accessed July 2018).

\section{PRODUCT DIVERSIFICATION AND VALUE CHAIN PARTICIPATION IN ASEAN}

\section{ASEAN exports have become more diversified in recent years.}

The Herfindahl-Hirschman concentration index $(\mathrm{HHCl})$ confirms the increasing product diversification of exports in the region. $\mathrm{HHCl}$ measures the dispersion of exports across an ASEAN economy's products by trade value. The closer the value of the index to 1, the more an economy's exports are concentrated in just a few products, while a lower value implies higher product diversification. The index of ASEAN countries shows a declining $\mathrm{HHCl}$ pattern from 2000 to 2016, except for Singapore (Figure 4). Brunei Darussalam, Cambodia, the Lao PDR, and Myanmar also have higher $\mathrm{HHCl}$ in 2010 compared to 2000, indicative of product concentration. However, more recently, with their increasing participation in regional value chains, $\mathrm{HHCl}$ indexes have also begun to drop. The increasing diversification of ASEAN exports bode well for the region since diversification is often associated with higher export growth and more stable export revenues.

\section{Diversification is also evident from the changing composition of gross and value-added exports-with the ranking of top industries and their shares shifting for most economies.}

For gross exports, from 2000 to 2016, the top industries for ASEAN members were mostly manufacturing industries. In exports, large economies - such as Malaysia, the Philippines, Singapore, and Thailand-have been consistent across years in their top industries, even if their rankings based on total share shifted slightly. For instance, in Thailand, machinery and transport equipment had top share in 2016, rising from fourth in 2000 , while electric and electronic products slipped to second. In small economies (and in Indonesia), the rankings of their top export industries changed over time with food, beverages, and tobacco 
becoming a major commodity in their export baskets. Rankings of top value-added exporting sectors also changed in 2015, with the share of food, beverages, and tobacco increasing to 14\% (ranked first), while electrical and optical equipment's share stayed at $12 \%$.

\section{SOPHISTICATION OF ASEAN EXPORTS}

\section{The technological content of ASEAN manufactured goods exports is improving; reflecting a catch-up process through technology transfer.}

For example, while the share of high-technology manufactures to total exports declined sharply after 2000, the combined share of high- and medium-technology manufactures rose from $58 \%$ in 2010 to 63\% in 2016 (Figure 5). This is indicative of a "catch-up" process for most ASEAN economies-part of the "flying geese model"-where the spread of their industrial growth replaces their overreliance on imports, which drives consumption and exports; and in tandem facilitates the shift from low-technology consumer goods to high-technology capital goods.

In the case of ASEAN, the catch-up is happening mainly in medium-technology industries. ${ }^{5}$ It is notable that the smaller ASEAN economies-such as Cambodia, Myanmar, and the Lao PDR - are also getting into medium-technology manufacturing and contributing to the region's greater technological sophistication.

\section{ASEAN exports' increasing technological sophistication could help the region benefit from increased trade tensions through redirected trade.}

However, research and development (R\&D) remains a key priority to help ASEAN economies (i) absorb and apply new technology, and (ii) develop indigenous high-tech industries. Latest data show that funding for R\&D in most of ASEAN (except Singapore)ranging from $0.1 \%$ of gross domestic product (GDP) in Cambodia to $0.6 \%$ in Thailand-pales in comparison with the average of $1.7 \%$ for upper middle-income countries. It is also much lower than the 2015 R\&D funding of the Republic of Korea (4.2\%); Japan (3.3\%); and the PRC (2.1\%).

\section{ASEAN has developed and maintained specialization in manufacturing electronic and electric raw materials and products, but recently it has also gained comparative advantage in other products.}

Between 2000 and 2016, the revealed comparative advantage (RCA) indexes for electronic products and electric raw materials and products have remained the highest, although it declined (Figure 6). This specialization reflects the strong exports of ASEAN's large economies-such as Malaysia, the Philippines, Singapore, and Thailand. During the same period, the RCA indexes for food, beverages, and tobacco; the manufacturing of leather, rubber, wood, and paper products; and miscellaneous manufactures have increased and exceeded one. This shows the growing importance of these products in the region's export basket, which could also provide a mechanism for ASEAN to benefit from escalating trade tensions via possible trade redirection effects. On the other hand, commodity exporting countries such as Brunei Darussalam, Indonesia, the Lao PDR, and Myanmar still hold comparative advantage for crude materials and mineral fuels.

Figure 4: ASEAN Exports Diversification: Herfindahl-Hirschman Concentration Indexes

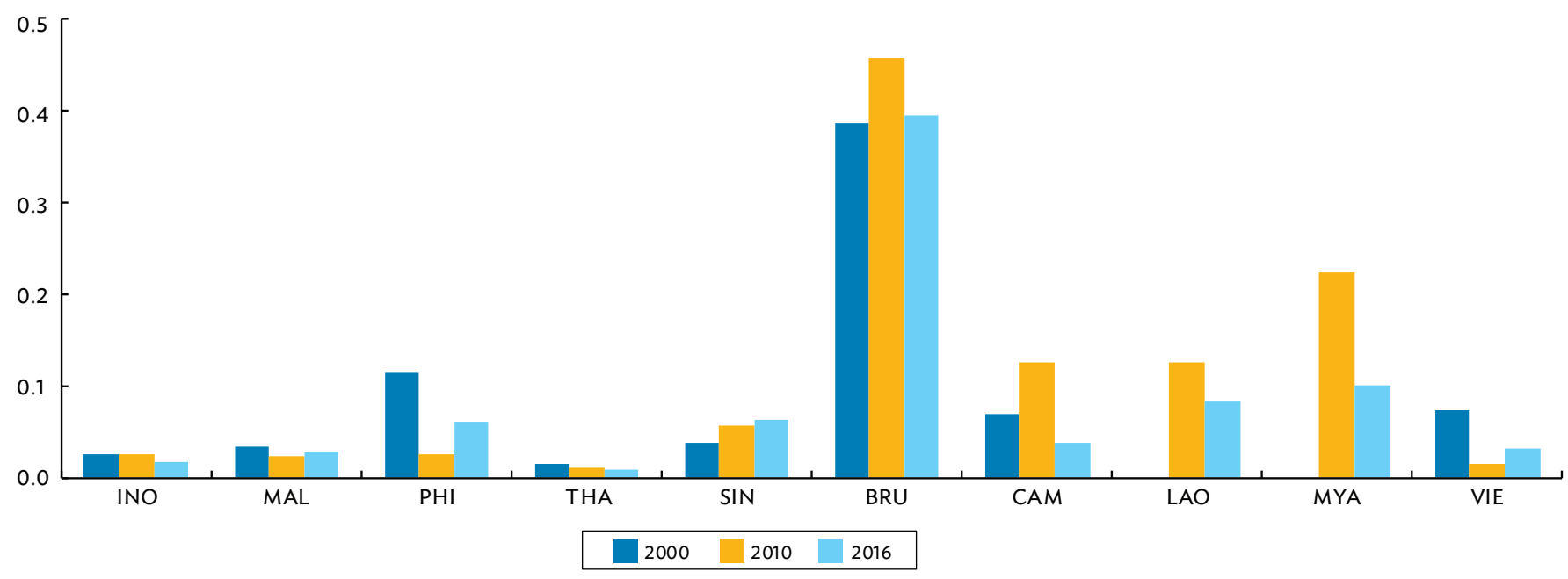

ASEAN = Association of Southeast Asian Nations, BRU = Brunei Darussalam, CAM = Cambodia, INO = Indonesia, LAO = Lao People's Democratic Republic, MAL = Malaysia, MYA = Myanmar, $\mathrm{PHI}=$ Philippines, $\mathrm{SIN}=$ Singapore, $\mathrm{THA}=$ Thailand, $\mathrm{VIE}=$ Viet Nam .

Note: Commodity classifications were based from the Standard International Trade Classification (Rev. 3).

Source: ADB calculations using data from World Bank. World Integrated Trade Solution Database. https://wits.worldbank.org (accessed July 2018).

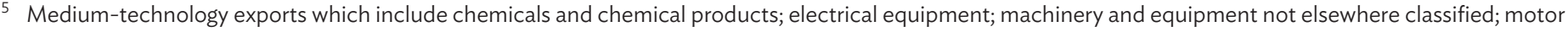

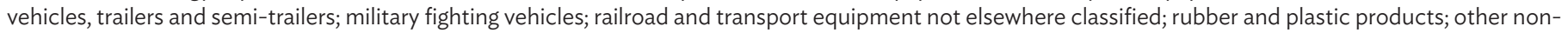
metallic mineral products; basic metals; building of ships and boat; and furniture manufacturing.
} 
Figure 5: ASEAN Manufacturing Exports by Technology Level (\% share to total exports)

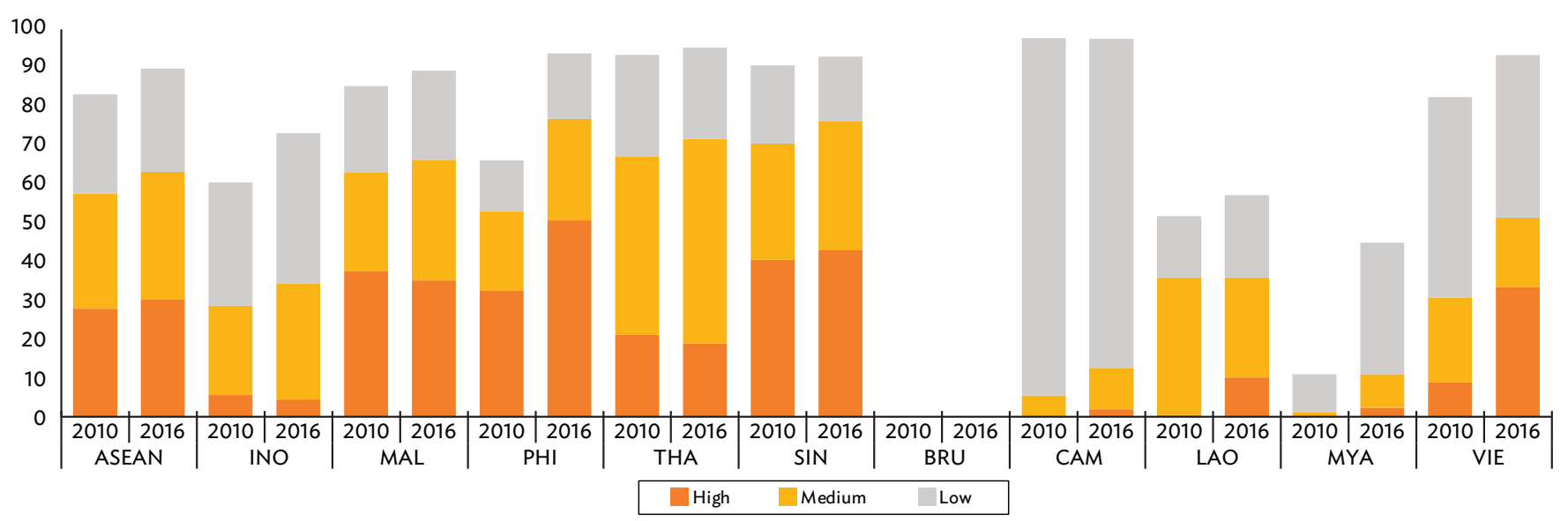

ASEAN = Association of Southeast Asian Nations, BRU = Brunei Darussalam, CAM = Cambodia, INO = Indonesia, LAO = Lao People's Democratic Republic, MAL = Malaysia, MYA = Myanmar, PHI = Philippines, SIN = Singapore, THA = Thailand, VIE = Viet Nam.

Notes: Low-technology industries include food, beverages and tobacco; textiles, leather and footwear; wood and products of wood and cork; paper and printing; coke and refined petroleum products; fabricated metal products; and other furniture manufacturing. Medium-technology industries include chemicals and chemical products; electrical equipment; machinery and equipment not elsewhere classified; motor vehicles, trailers and semi-trailers; military fighting vehicles; railroad and transport equipment not elsewhere classified; rubber and plastic products; other nonmetallic mineral products; basic metals; building of ships and boat; and furniture manufacturing. High-technology industries include aircraft and spacecraft; pharmaceuticals; and computer, electronic, and optical products. Shares do not add up to $100 \%$ due to some unclassified exports.

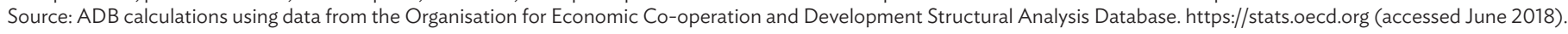

\section{VULNERABILITIES AND CHALLENGES FACING ASEAN}

\section{Despite these relatively positive developments, ASEAN continues to face challenges related to (i) narrow product space, (ii) a limited degree of complementarity, and (iii) a need to improve business competitiveness.}

Generally, ASEAN can be grouped into three in terms of product diversity. Group 1 comprises Malaysia, Singapore, and Thailandeconomies that successfully transformed from agriculture to export-oriented manufacturing and integrated strongly into regional and global value chains. Group 2 comprises Indonesia, the Philippines, and Viet Nam-economies that have expanded their export basket to include more complex products, with a moderate diversification away from primary resources. They are also integrating gradually into regional and global value chains. However, group 3-Brunei Darussalam, Cambodia, the Lao PDR, and Myanmar-comprises economies that still have a narrow export base that is highly concentrated on resourcebased products.

Exports of group 3 are naturally more volatile, compared to the other two groups, as they are greatly affected by demand disruptions and price shocks. More so, a large proportion of their labor-intensive exports-such as garments, footwear, and other textile products-also go to slow-moving markets such as Europe and the US. Therefore, to build greater resilience, these countries need to diversify exports, upgrade productive capabilities, and improve their competitiveness to join the regional value chain.

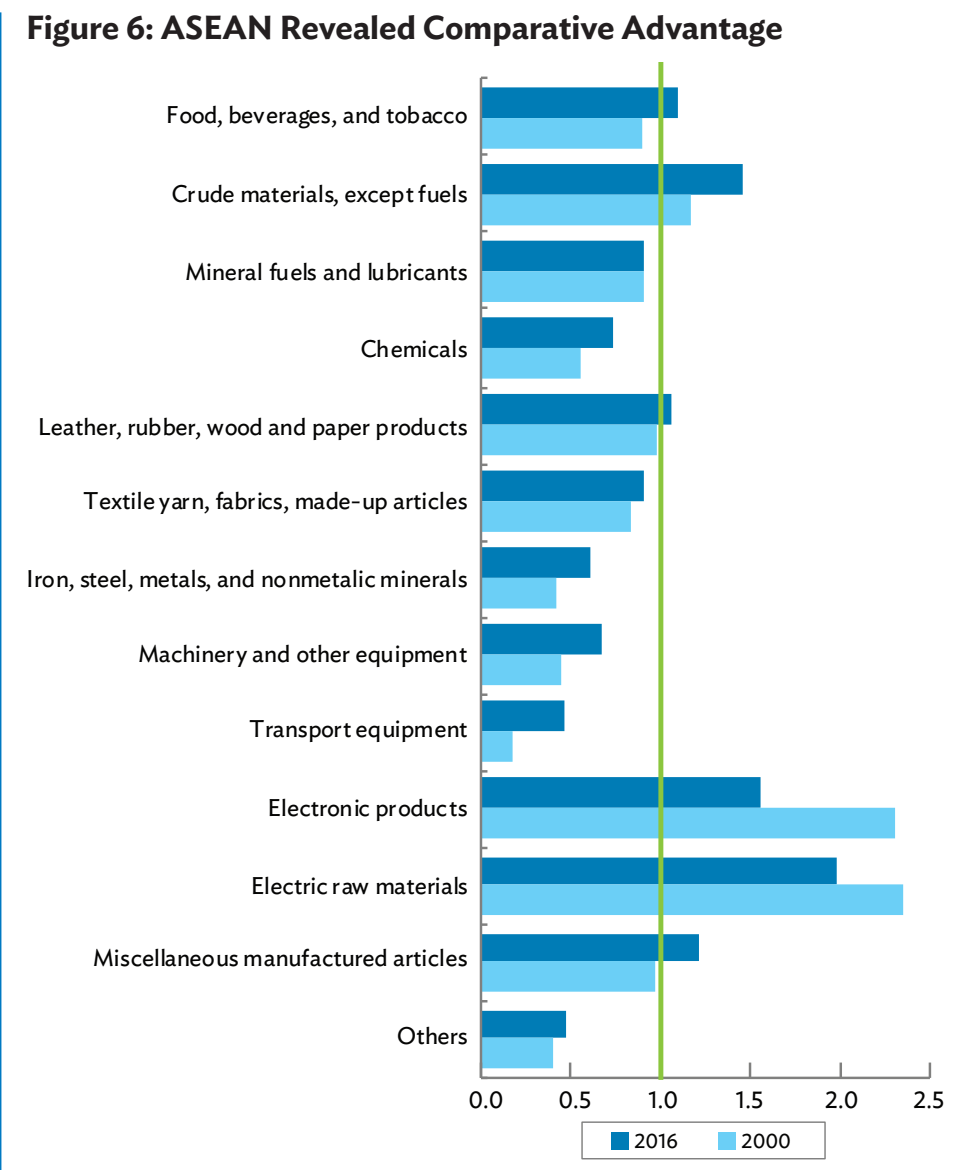

ASEAN = Association of Southeast Asian Nations.

Note: Commodity classifications were based on the Standard International Trade Classification (Rev. 3).

Source: ADB calculations using data based on the United Nations Commodity Trade Statistics Database. https://comtrade.un.org (accessed May 2018). 
While ASEAN4, Singapore, and Viet Nam maintain moderately strong "trade complementarity," Brunei Darussalam, Cambodia, the Lao PDR, and Myanmar lag behind.

Based on a measure of trade complementarity, Indonesia, Malaysia, the Philippines, Thailand, and Singapore have moderately strong complementarity with indexes above 0.35 for all ASEAN trading partners (Table 1). ${ }^{6}$ The pair of countries with the highest trade complementarity was Malaysia and Singapore; this was followed by Malaysia-Philippines, Singapore-Philippines, SingaporeIndonesia, Thailand-Malaysia-Philippines, and Thailand-Viet Nam-Malaysia. However, Brunei Darussalam, Cambodia, the Lao PDR, and Myanmar had low trade compatibility with other ASEAN economies, and building trade complementarity is still a challenge.

Similarly, while groups 1 and 2 benefit from an improved business environment, group 3 economies also suffer from high transaction costs even though they work to improve their business environment.

This stems from poor quality infrastructure, a still nascent financial sector, and lack of access to financing, among others. The World Bank's Ease of Doing Business Index 2018 shows Cambodia, the Lao PDR, and Myanmar ranked at the bottom third out of 190 economies. ${ }^{7}$ This partly explains their low trade complementarity and integration in the regional value chain and remains a key challenge for the region.

\section{BUILDING COMPLEMENTARITY AND RESILIENCE IN ASEAN}

Three policy actions are crucial for building complementarity and resilience in ASEAN.

Structural policy reforms are central for improving the business and investment environment.

Enhancing the business environment, investing in quality infrastructure, facilitating access to finance, boosting labor quality, and promoting innovation-are policy areas where improvements will make ASEAN more efficient, productive, and competitive.

The World Economic Forum's Global Competitiveness Report 2017-2018 identified inadequate supply of infrastructure or access to finance as impediments to doing business in Cambodia, Indonesia, the Lao PDR, Malaysia, the Philippines, and Viet Nam. Limited access to finance and financial services continue to be a problem for most private firms, particularly small and mediumsized enterprises (SMEs). Access to finance also remains a problem for new entrants and innovators - partly behind one country's limited product diversity. More so, poor infrastructure hinders the country's competitiveness globally. For instance, disparities in infrastructure can limit a country's ability to benefit from regional initiatives. And removing excessive and unnecessary regulations in product, labor, and financial markets are also reforms that help the business environment.

Table 1: Trade Complementarity Index by ASEAN Trade Partner, 2013

\begin{tabular}{|c|c|c|c|c|c|c|c|c|c|c|}
\hline \multirow{2}{*}{ Reporter } & \multicolumn{10}{|c|}{ Partner } \\
\hline & BRU & CAM & INO & LAO & MAL & MYA & PHI & SIN & THA & VIE \\
\hline BRU & & 0.02 & 0.09 & 0.02 & 0.06 & 0.04 & 0.12 & 0.13 & 0.20 & 0.02 \\
\hline CAM & 0.13 & & 0.10 & 0.09 & 0.11 & 0.09 & 0.10 & 0.08 & 0.08 & 0.10 \\
\hline INO & 0.28 & 0.28 & & 0.24 & 0.36 & 0.32 & 0.36 & 0.31 & 0.37 & 0.31 \\
\hline LAO & 0.08 & 0.11 & 0.09 & & 0.14 & 0.06 & 0.10 & 0.06 & 0.10 & 0.09 \\
\hline MAL & 0.40 & 0.33 & 0.48 & 0.41 & & 0.38 & 0.59 & 0.64 & 0.49 & 0.50 \\
\hline MYA & 0.09 & 0.05 & 0.08 & 0.04 & 0.11 & & 0.07 & 0.07 & 0.11 & 0.09 \\
\hline PHI & 0.31 & 0.24 & 0.34 & 0.32 & 0.53 & 0.26 & & 0.48 & 0.41 & 0.36 \\
\hline SIN & 0.39 & 0.41 & 0.53 & 0.48 & 0.63 & 0.43 & 0.56 & & 0.43 & 0.48 \\
\hline THA & 0.47 & 0.42 & 0.51 & 0.49 & 0.53 & 0.40 & 0.47 & 0.44 & & 0.51 \\
\hline VIE & 0.33 & 0.29 & 0.38 & 0.26 & 0.36 & 0.28 & 0.37 & 0.34 & 0.38 & \\
\hline
\end{tabular}

"low" complementarity, with trade complementarity index ( $\mathrm{TCl}$ ) of below 0.30

"medium" complementarity, with $\mathrm{TCl}$ between 0.30 and 0.50

"high" complementarity, with $\mathrm{TCl}$ above 0.50

ASEAN = Association of Southeast Asian Nations, BRU = Brunei Darussalam, CAM = Cambodia, INO = Indonesia, LAO = Lao People's Democratic Republic, MAL $=$ Malaysia, MYA = Myanmar, $\mathrm{PHI}=$ Philippines, $\mathrm{THA}=$ Thailand, $\mathrm{VIE}=$ Viet Nam.

Source: ADB calculations using data from the United Nations Conference on Trade and Development. Data Center. http://unctadstat.unctad.org (accessed December 2017).

6 For this analysis, a complementarity index-a similarity measure of export and import structures for a pair of countries-is used to examine if the pairwise structure of exports and imports between two trading partners are broadly similar. The trade complementarity index is valued between 0 and 1 , where 1 is perfect complementarity (or matching) and 0 means no complementarity. The index reflects the gains of two countries when one holds comparative advantage over the other. 
Maintaining open trade and investment policies are needed to attract foreign direct investment-an important element for export-oriented development strategies.

Inward foreign direct investment (FDI) to ASEAN increased more than sixfold between 2000 to 2017, growing from $\$ 22$ billion to $\$ 134$ billion. FDI inflows to ASEAN were equivalent to 5\% of GDP in 2017 (up from 3\% in 2000). During the past 17 years, FDI grew at an annual average of $11 \%$ - with Cambodia, the Lao PDR, Myanmar, and Viet Nam showing the most robust growth. Greenfield investments have remained the predominant mode of entry for foreign investors, accounting for at least $65 \%$ of total inflows since 2003-and mainly in manufacturing products that are relatively better linked to cross-border value chains. By comparison, investment through mergers and acquisitions-primarily in services-has also gained increasing shares in recent years, driven primarily by expanding domestic markets.

\section{Asia remains the most important source of inward FDI in ASEAN; and the prospects for strengthening intra-ASEAN investment linkages are also bright.}

Similarly, ASEAN's strong relationship with neighboring Asian economies-especially East Asia-offers strong potential for shoring up investments. Between 2003 and 2017, FDI from Asia accounted for $59 \%$ of total inflows to ASEAN. East Asia's share of ASEAN's total investment flows rose to 49\% in 2017 from $26 \%$ in 2003, mostly through greenfield investments in manufacturing. ${ }^{8}$ Intra-ASEAN investment linkages have also strengthened over time, with the share in inward FDI rising from 11\% in 2003 to $22 \%$ in 2015 (declining to 13\% in 2017). ${ }^{9}$ Singapore, Malaysia, and Thailand were the largest investors.

\section{ASEAN could maximize potential opportunities for investment growth by improving the region's business environment and attractiveness on its trade and investment complementarity.}

The resulting decline and continued slowdown in trade and investment activity between the US and the PRC could result in increasing investment diversion to alternate locations. For instance, there could be potential opportunities in manufacturing technology and agriculture within ASEAN..$^{10}$ For example, US companies in the PRC operating in manufacturing technology supply chains could relocate production to Malaysia, Thailand, and Viet Nam. The PRC may access ASEAN economies (such as Thailand) for food imports due to their potential retaliatory tariffs against US agricultural products. The acceleration of intraASEAN trade in recent years also presents an opportunity for investment growth within the region-given attempts to increase complementarity of trade and investment in the region.
Services liberalization can also help promote services trade in ASEAN.

\section{Given the increasing importance of services in ASEAN economies, promoting services liberalization can create new opportunities for trade and FDI growth.}

By and large, services contribute significantly to GDP_-in creating jobs and providing necessary inputs for economies to thrive.

ASEAN countries can benefit from increased services exports as they expand their services industries, which produce higher growth, more jobs, and greater foreign exchange earnings. Liberalizing the imports of services or the entry of foreign service providers can also bring greater competition, international best practices, better skills and technologies, and investment capital.

\section{Generally, further liberalization, regulatory services reform, privatization, increased fragmentation of services production, and the proliferation of information and communication technology-dependent production networks are contributing factors behind the rise of FDI in services in the region.}

As regional production networks become more sophisticated and capital-intensive, there has been a shift toward more advanced, technology-based production. There have been increased FDI flows in sectors enabled by information and communication technology and other advanced industries -including financial services, business services, health care, warehousing and storage, and alternative or renewable energy, among others.

\section{This trend has also contributed to expanded services trade in the region which is further strengthening intra-ASEAN services trade linkages.}

For instance, while services trade boom has generally been concentrated in tourism-related industries - such as transport and travel-for most economies in ASEAN (such as Cambodia, the Lao PDR, Myanmar, and Thailand); trade growth has also grown in business services, telecommunications, and computer and information services in the Philippines, Singapore, and Viet Nam. ${ }^{11}$ This divergence in comparative advantage in services across ASEAN economies indicates a potential opportunity for enhancing intraregional services trade.

\footnotetext{
7 See Table A1 in online appendix: https://aric.adb.org/pdf/ASEANtrade_appendix

8 In particular, Japan, the PRC, and the Republic of Korea have been among the largest investors in ASEAN. Over the years, ASEAN countries-especially

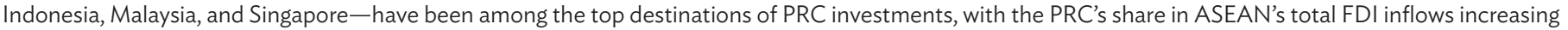
from $1 \%$ in 2003 to $12 \%$ in 2017.

9 Notwithstanding the decline of intra-ASEAN FDI in 2017, it was still 60\% higher in the last 5 years compared with the average level from $2003-2012$.

10 K. Tang. 2018. How ASEAN's 3Rs Can Overcome Trade Wars. https://en.nikkoam.com/articles/2018/04/how-aseans-3rs-can-overcome-trade-wars

11 See Figure A1 in online appendix: https://aric.adb.org/pdf/ASEANtrade_appendix
} 


\section{ENHANCING REGIONAL COOPERATION TO BUILD RESILIENCE}

\section{Regional cooperation and integration can also add resilience} to ASEAN.

\section{The ASEAN Economic Community is a game changer for the region.}

Despite the 2008/09 global financial crisis, the fragile global recovery and growth moderation in the PRC, ASEAN economies have maintained their robust growth. This partly stems from the ASEAN Economic Community (AEC) which continues to create greater synergy among ASEAN economies as it deepens its large single market. The AEC is also helping expand the regional demand base and creating a buffer for the region against external shocks. The AEC can also help ASEAN tap the advantage of a young, eager, and literate labor force-which can benefit from greater regional mobility. The AEC can also help improve the national business climate to attract greater FDI-particularly to smaller ASEAN economies. In turn, this will help extend forward and backward linkages among manufacturing firms and small and medium-sized enterprises in various ASEAN economies. In the near term, the solid progress in attaining the AEC Blueprint 2025 will likely propel regional cooperation further.

\section{Greater regional cooperation and integration efforts can also help diversify ASEAN economic and trade structures, upgrade its competitiveness and productive capacity, and speed up domestic and regulatory reforms-building greater complementarity and resilience in the process.}

For instance, promoting greater regional cooperation and integration could help ASEAN increase market size, exploit economies of scale, enhance competition, and increase capital and technology transfers. Presently, regional mega free trade agreements (FTAs) involving members of the Association of Southeast Asian Nations (ASEAN). The revised Comprehensive and Progressive Agreement for Trans-Pacific Partnership (CPTPP) and the Regional Comprehensive Economic Partnership (RCEP)continue to progress, despite escalating trade tensions between the US and the PRC. Speeding up RCEP implementation will lock in trade gains from existing FTAs among RCEP members and promote deeper integration in goods and services trade and investment in ASEAN markets. ${ }^{12}$ It will also create trade and investment opportunities for RCEP members that do not have FTAs with other members (the PRC, Japan, and the Republic of Korea).

\section{The outline of the RCEP agreement includes comprehensive provisions not covered in ASEAN FTAs.}

Except for the ASEAN-Australia-New Zealand FTA, ASEAN FTAs have focused more on liberalization of trade in goods. ${ }^{13}$ While tariffs are now generally low, nontariff measures or "behindthe-border" trade impediments remain significant. ${ }^{14}$ Most ASEAN FTAs do not address these "behind-the-border" issues because they do not include other integration provisions such as competition, intellectual property, and electronic commerce. Also, no ASEAN FTA includes a provision for government procurement. By expanding these integration provisions, RCEP advances trade openness to a level beyond tariff elimination and creates opportunities for further trade and investment.

12 RCEP includes members of ASEAN and its six FTA partners, a grouping that includes about $50 \%$ of the world's population, $32 \%$ of its GDP, and $29 \%$ of global trade. RCEP economies have the largest combined GDP among all alternatives examined by P.A. Petri, M.G. Plummer, S. Urata, and F. Zhai. 2017. Going It Alone in the Asia-Pacific: Regional Trade Agreements Without the United States. Working Paper. Washington: Peterson Institute for International Economics.

13 See Table A2 in online appendix: https://aric.adb.org/pdf/ASEANtrade_appendix

${ }^{14}$ ADB. 2017. Asian Economic Integration Report 2017. Manila.

Asian Development Bank

$A D B$ is committed to achieving a prosperous, inclusive, resilient, and sustainable Asia and the Pacific, while sustaining its efforts to eradicate extreme poverty. Established in 1966, it is owned by 67 members48 from the region. Its main instruments for helping its developing member countries are policy dialogue, loans, equity investments, guarantees, grants, and technical assistance.

ADB Briefs are based on papers or notes prepared by ADB staff and their resource persons. The series is designed to provide concise, nontechnical accounts of policy issues of topical interest, with a view to facilitating informed debate. The Department of Communications administers the series.
The views expressed in this publication are those of the authors and do not necessarily re ect the views and policies of ADB or its Board of Governors or the governments they represent. ADB encourages printing or copying information exclusively for personal and noncommercial use with proper acknowledgment of ADB. Users are restricted from reselling, redistributing, or creating derivative works for commercial purposes without the express, written consent of ADB.

Asian Development Bank 6 ADB Avenue, Mandaluyong City 1550 Metro Manila, Philippines

Tel +6326324444

Fax +6326362444

www.adb.org/publications/series/adb-briefs 